Fragmenta FaUnistica 53 (2): 213-231, 2010

PL ISSN 0015-9301C Museum AND Institute of ZoOLOGY PAS

\title{
Amphibian communities in small water bodies in the city of Olsztyn
}

\author{
Jacek J. Nowakowski, Andrzej Górski and Krzysztof Lewandowski
}

Department of Ecology \& Environmental Protection, University of Warmia and Mazury in Olsztyn, Plac Lódzki 3, 10-727 Olsztyn, Poland; e-mail: jacek.nowakowski(âwm.edu.pl

\begin{abstract}
The aims of the study were determine the effects of anthropogenic pressure on the species composition and population size of amphibians of small water bodies in Olsztyn city (NE Poland). The presence of 11 amphibian species was noted in $83.5 \%$ of water bodies. The dominants were: the common frog Rana temporaria, the edible frog Rana esculenta, the pool frog Rana lessonae, the common toad Bufo bufo and the moor frog Rana arvalis. The fire-bellied toad Bombina bombina was an influent, while the common newt Triturus vulgaris, the common spadefoot Pelobates fuscus, the tree frog Hyla arborea, the green toad Bufo viridis and the crested newt Triturus cristatus were the recedents. The most frequent were "green frogs", which occur in $71.9 \%$ of water bodies inhabited by amphibians $(60.0 \%$ of all water bodies). The species characterized by the lowest occurrence frequency were the tree frog $(6.0 \%$ and $5.0 \%$, respectively), the green toad (5.4\% and 4.5\%) and the crested newt (3.6\% and 3.0\%). In the paper the urban pressure on amphibian communities is widely discussed.
\end{abstract}

Key words: amphibians, urban habitat, small water reservoirs

\section{INTRODUCTION}

The decrease in species diversity and the population size of batrachofauna has been widely discussed by contemporary researchers (Green 1995, Alford \& Richards 1999, Houlahan et al. 2000, Krzyściak-Kosińska 2000, Stuart et al. 2004, Beebee \& Griffiths 2005). Factors whose individual and combined effect may directly and indirectly contribute to the above include changes in UV spectrum radiation that influence the reproductive performance and survival of amphibians (Blaustein et al. 1995, Long et al. 1995, Blaustein et al. 2003, Ovaska et al. 1997), climate change (Bebee 1995, Corn 2005, Wake 2007), predation and competition posed by introduced species (Bradford 1991, Fisher \& Shaffer 1996), disease and immunosuppression (Kiesecker \& Blaustein 1995, Laurance et al. 1996, Daszak 2003, Rohr \& Raffel 2010), environmental pollution (Rouse et al. 1999, Corn 2000, Sparling et al. 2000), transformations of water-logged ecosystems (Johnson 1992, Lannoo et al. 1994, Collins \& Storfer 2003), environmental degradation caused by human activity, industrialization and urbanization (Corn 2000, Brooks et al. 2002, Stuart et al. 2004).

According to Cushman (2006) and Hamer \& McDonnell (2008), the degradation, fragmentation and isolation of ecosystems are the main anthropogenic factors responsible for the drop in amphibian populations. Intensive urbanization efforts are observed 
around the world, in particular in Europe (Antrop 2004). This process is one of the strongest manifestations of human pressure on the natural environment (Vitousek et al. 1997, McKinney 2002, Miller \& Hobbs 2002).

Research results indicate that urbanization exerts a powerful effect on animal habitats, leading to a drop in species diversity, the domination of ubiquitous species, population change and behavioral adaptation (Sukopp \& Werner 1982, Dickman 1987, Mills et al. 1989, Blair 1996, Markowski 1997, Luniak 1998, Marzluff 2001).

The urban environment is characterized by specific ecological factors, including higher annual temperatures than in the surrounding areas, lower humidity, disrupted structure and chemical composition of soils, chemical contamination, structurally impoverished plant systems, acoustic climate, traffic intensity and a high level of ecosystem isolation (Karolewski 1981, Breuste et al. 1998, Zimny 2005). Due to various anthropogenic factors, water bodies and the surrounding terrestrial habitats in urban areas are subject to strong degradation, disappearance and isolation. During the reproductive season, amphibians have very specific preferences as regards the size, depth, vegetation cover and water chemistry of aquatic breeding sites (Strijbosch 1979, Beebee 1996, Hamer \& McDonnell 2008).

In view of the global decline in amphibian populations and their species diversity, the adverse impact of environmental transformations and intensified urbanization, Pasmans et al. (2006) have postulated the need for more in-depth studies analyzing amphibian populations throughout Europe. The ecology of amphibian habitats in urban areas of Central Europe remains weakly researched. The existing batrachofauna inventories cover, among others, the cities of Brno (Král et al. 1983), Kraków (Juszczyk 1989, Guzik et al. 1996), Poznań (Pawlowski 1993), Warszawa (Mazgajska 1996, 1998), Olsztyn (Nowakowski et al. 1998, 2008), Wroclaw (Kierzkowski \& Ogielska 2001) and Zielona Góra (Najbar et al. 2005). In Łódź, only the amphibians of the Łagiewnicki Forest, situated within the city's administrative boundaries, have been evidenced (Stopczyński et al. 2004). The environmental factors determining the species composition and the size of amphibian populations inhabiting urban water bodies during the reproductive season have not been investigated in detail, and such knowledge is very valuable in classifying breeding sites for conservation purposes.

Olsztyn is a city with a well developed hydrographic network. It features numerous lakes and small, stagnant water bodies, which are subject to typical urban pressure in a rapidly growing city. Olsztyn's water bodies are becoming increasingly isolated as continued efforts are made to expand the local transportation network.

The objectives of this study were to: 1) characterize the species composition and population size of amphibians in small water bodies in Olsztyn;2) determine the effects of anthropogenic pressure on the structure and size of amphibian populations.

\section{STUDY AREA}

Olsztyn - city in North-East Poland $\left(53^{\circ} 783^{\prime} \mathrm{N}, 20^{\circ} 483^{\prime} \mathrm{E}\right)$ is situated at the altitude of $88.0 \mathrm{~m}$ a.s.l. (Lyna River near the Redykajny housing estate) to $150.8 \mathrm{~m}$ a.s.l. (Pie- 
czewo district). The city lies in the center of the physical and geographic mesoregions of the Olsztyn Lakeland, a part of the Masurian Lakeland macroregion (Kondracki 2002), and it occupies the area of $87.9 \mathrm{~km}^{2}$. The studied physiographic region features a range of end moraines dating back to the Würm glaciation, referred to as the Lyna river lobe, underlain by boulder clay. The local topography is typical of the region's lake districts with numerous moraine hills, kames, moraine valleys and sinkholes without stream outflow. In the north and north-west, Olsztyn is occupied by forests and the Wadag River valley. There is a predominance of open areas in the southern and south-eastern parts of the city.

The valley of the Łyna River divides Olsztyn meridionally into two parts. The western part is occupied by single-family housing (estates of Dajtki, Likusy, Gutkowo, Nad Jeziorem Dlugim, Sloneczny Stok). Green areas cover a vast part of western Olsztyn, and they comprise 11 lakes (Czarne - 1.5 ha, Dlugie -26.8 ha, Kortowskie -89.7 ha, Redykajny -29.9 ha, Sgnitek -6.0 ha, Siginek -6.9 ha, Stary Dwór -7.0 ha, Sukiel -20.8 ha, Tyrsko -18.6 ha, Ukiel -412 ha, Żbik -1.4 ha). The eastern part of the city features mostly apartment blocks, single-family houses and industrial facilities. Green areas with three lakes (Pereszkowo - 1.8 ha, Skanda -51.1 ha, Track -52.8 ha) are found in the city's eastern suburban zone.

Olsztyn's hydrographic network comprises more than 200 small water bodies, both permanent and intermittent (Figs. 1,2). According to location the water bodies have been classified into the following categories: 1 - situated in dense urban areas ( 3 water bodies, $1.5 \%) ; 2$ - situated in urban areas with scattered, low-rise buildings (22; 11\%); 3 - located in municipal parks of Jakubowo, Janusza Kusocińskiego, Jar 1 and Track $(6 ; 35) ; 4$ - situated in suburban forests $(10 ; 5 \%) ; 5$ - located in open, ruderal areas with some industrial activity $(26 ; 13 \%) ; 6$ - situated in open, ruderal areas minimally transformed by human activity and mid-field ponds (114; 57\%); 7 - located in allotment gardens $(7 ; 3.5 \%) ; 8$ - water bodies in the ecotone between open and wooded areas $(10 ; 5 \%)$. Small water bodies occupy a total area of 114.368 ha, accounting for $1.3 \%$ of Olsztyn`s surface area.

\section{Materials and Methods}

The study was carried out in 1997-1998. All (200) of Olsztyn's small water bodies were surveyed in 1997, while in 1998, only 80 randomly selected bodies were monitored. Amphibians inhabiting two small lakes with the area of around 1 ha were not accounted for in this study, and the relevant information was presented in a previous research paper (Nowakowski et al. 1998).

In all surveyed sites, species abundance was determined by waterside surveys and evaluations of mating calls. Every water body was monitored 3-4 times during the season. The presence of amphibian spawns and larvae was determined in water bodies. Owing to their morphological variation and the uncertainty of determinations, the pool frog Rana lessonae Camerano, 1882 and the edible frog Rana kl. esculenta Linnaeus, 


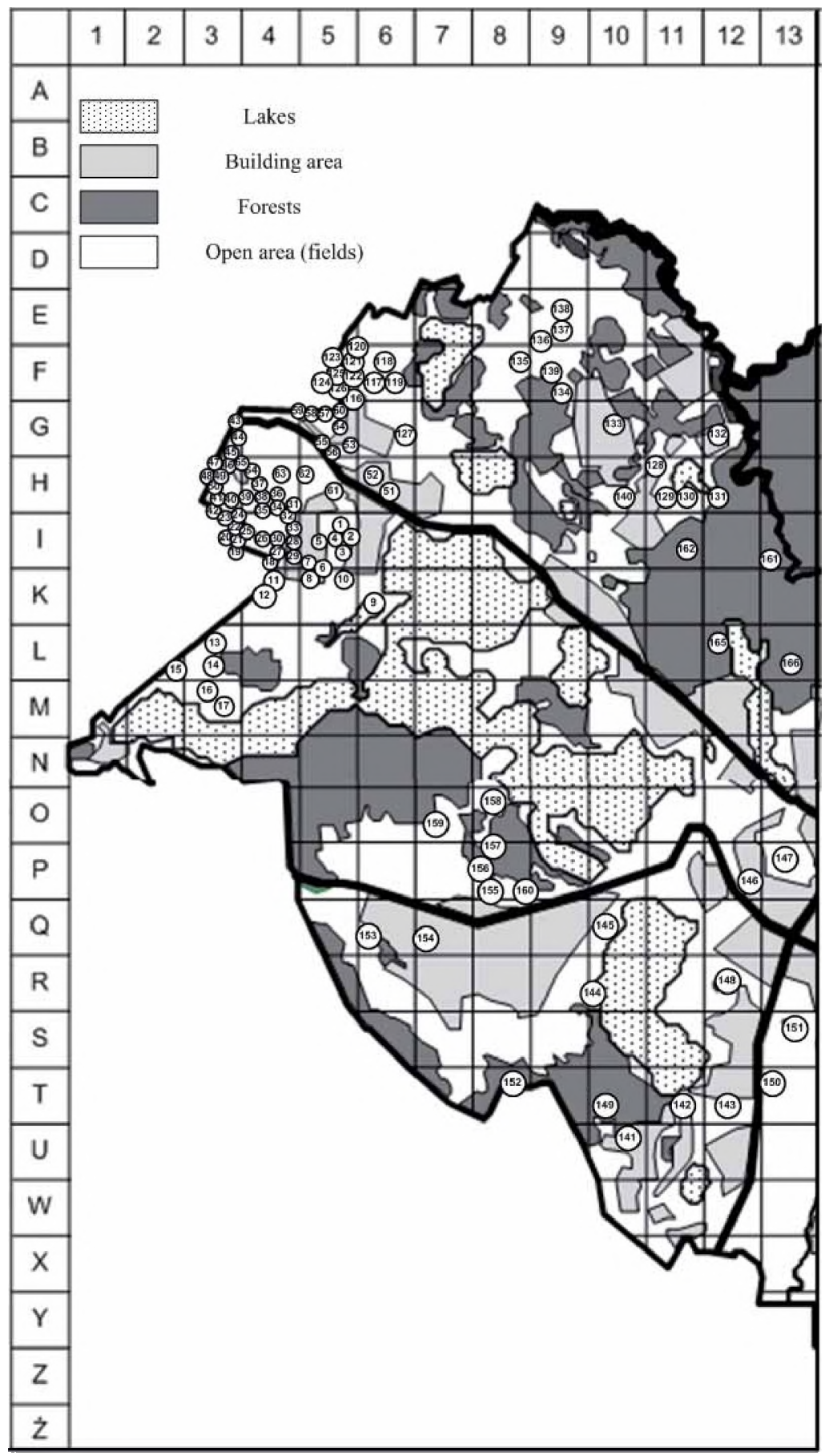

Fig. 1. Distribution of the main types of environments and small water bodies within Olsztyn's administrative boundaries in the western part of the city; atlas square is a 500x500m area; lines based on topographic net. 


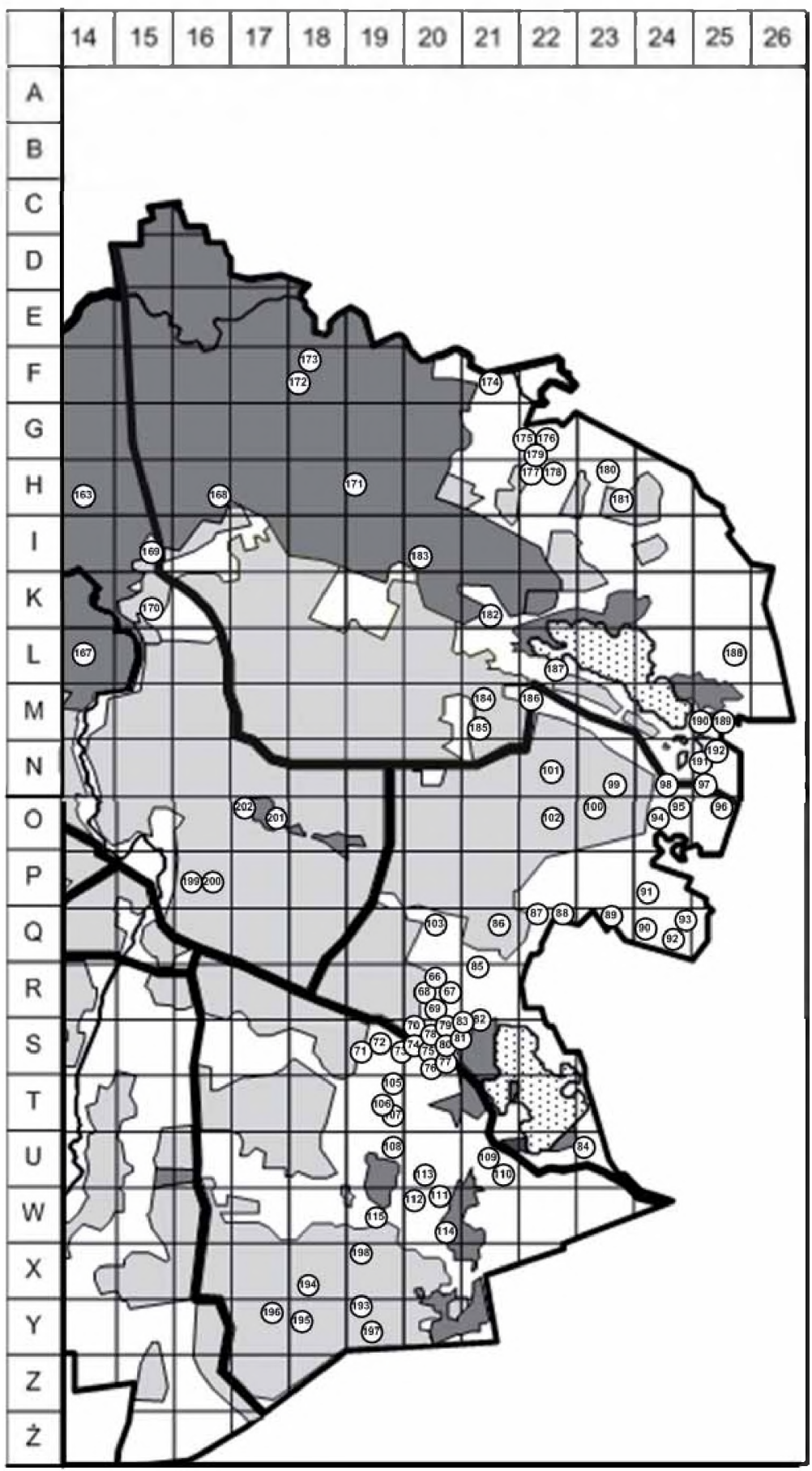

Fig. 2. Distribution of the main types of environments and small water bodies within Olsztyn's administrative boundaries in the eastern part of the city; atlas square is a $500 \times 500 \mathrm{~m}$ area; lines based on topographic net. 
1758 were classified collectively in the group of "green frogs" (Rana esculenta complex).

The abundance of species in the investigated water bodies was determined on a base- $2 \mathrm{x}$-scale, where 1 denoted up to 5 individuals, 2 - up to 10 individuals, 3 - up to 20,4 - up to 40,5 - up to 80,6 - up to 160,7 - up to 320,8 - up to $640,9-$ up to 1280, and 10 - above 1280 individuals.

Estimation of the average number of individuals of a given species in each water bodies was delivered based on mid-range values of the adopted evaluation scale. Numbers of species abundance in a given season was estimated based on the above values.

Species dominance was characterized based on the following domination classes: dominants - above $5.01 \%$, subdominants $-2.01 \%$ to $5.00 \%$, influents $-1.01 \%$ to $2.00 \%$, and recedents - up to $1.00 \%$.

The species structure of amphibian communities in Olsztyn was compared with those in other cities using the hierarchical cluster analysis and the Manhattan distance for binary data.

\section{RESULTS}

A total of 200 small water bodies were monitored in Olsztyn in 1997-1998. The presence of amphibians was noted in 167 water bodies (83.5\%), while the remaining 33 bodies $(16.5 \%)$ were not colonized by amphibian species. 73 ecosystems inhabited by amphibians were intermittent water bodies, and the remaining 94 were permanent water bodies with a relatively high water stage.

A total of 11 amphibian species were determined in Olsztyn. The dominants were: the common frog Rana temporaria Linnaeus, 1758, the edible frog Rana esculenta Linnaeus, 1758, the pool frog Rana lessonae, Camerano, 1882, the common toad Bufo bufo (Linnaeus, 1758) and the moor frog Rana arvalis Nilsson, 1842. The fire-bellied toad Bombina bombina (Linnaeus, 1761) was an influent, while the common newt Triturus vulgaris (Linnaeus, 1758), the common spadefoot Pelobates fuscus (Laurenti, 1768), the tree frog Hyla arborea (Linnaeus, 1758), the green toad Bufo viridis, Laurenti, 1768 and the crested newt Triturus cristatus (Laurenti, 1768) were members of the recedent group. The above 11 species have a $61 \%$ share of all amphibian species in Poland and a $85 \%$ share of all amphibian species observed in north-eastern Poland (as cited in Glowaciński \& Rafiński 2003).

The most popular taxon in Olsztyn's small water bodies were "green frogs" which were observed in $71.9 \%$ of water bodies inhabited by amphibians $(60.0 \%$ of all water bodies). It was followed by the common frog whose presence was determined in $64.1 \%$ of water bodies colonized by amphibians (53.5\% of all water bodies). Less frequent were the common toad (37.2\% of water bodies inhabited by amphibians and $31.0 \%$ of all water bodies), the moor frog ( $26.3 \%$ and $22.0 \%$, respectively), the European fire-bellied toad found in 21 water bodies ( $12.6 \%$ and $10.5 \%$, respectively), the common newt noted in 20 water bodies ( $12.0 \%$ and $10.0 \%$, respectively) and the common spadefoot 
observed in 19 water bodies ( $11.4 \%$ and $9.5 \%$, respectively). The species characterized by the lowest occurrence frequency were the tree frog which was reported in 10 water bodies $(6.0 \%$ and $5.0 \%$, respectively), the green toad found in nine water bodies $(5.4 \%$ and $4.5 \%$, respectively) and the crested newt reported in six water bodies ( $3.6 \%$ and $3.0 \%$, respectively).

The water bodies situated in dense urban areas comprised five taxa: "green frogs", the common frog, the green toad and the common toad. Urban areas with low-rise residential buildings were the habitat of four taxa: green frogs, the common frog and the common toad. Municipal parks and forests were dominated by "green frogs" and the common frog. The investigated parks showed a clear dominance of "green frogs" over the common frog and an abundance of the common newt and the green toad, which were not noted in mid-forest water bodies. A greater abundance of the common newt, the tree frog, the common spadefoot and the moor frog was observed in open areas and in the ecotone between open and afforested areas. The moor frog was particularly abundant in the ecotone zone. In 1997 the moor frog and the common frog occurred in a lower numbers compared to 1998 . The common newt was found to be the dominant taxon in allotment gardens and in the water bodies of the ruderal, strongly transformed zone (Table 1).

An average of two amphibian species per water body was determined (Table 2). No significant variations in the average number of species were found subject to the type of the aquatic environment (median test: $\chi^{2}=11.524, \mathrm{df}=7, \mathrm{p}=0.117$ ), although the lowest total number of species was observed in municipal parks and allotment gardens (Table 1). Water bodies in dense urban areas were inhabited by three to five species, showing the highest average number of species (Table 2), but the average measure resulted from the small size of the sample (three water bodies) as well as the fact that mid-field water bodies were included in urban areas relatively recently in reference to the experimental period (after 1995).

Water bodies inhabited by amphibians were colonized by one to nine species. Aquatic ecosystems with one to three species had more than a $50 \%$ share of all water bodies where amphibians were determined, while habitats featuring four to five species accounted for $20 \%$ of the studied ecosystems. Very few water bodies were colonized by a higher number of species (Fig. 3).

\section{Discussion}

The species composition of amphibian communities in Olsztyn, comprising a total of 11 species, is similar to that noted in other large Polish cities, including Bialystok ( $\mathrm{Si}$ wak et al. 2000), Wroclaw (Kierzkowski \& Ogielska 2001) and Warszawa (Mazgajska 2008). The greatest differences were observed in respect of the amphibian communities of Zielona Góra (Najbar et al. 2005) (Fig. 4). In comparison with the investigated water bodies in Olsztyn, a higher number of amphibian species was reported in Warszawa (Mazgajska 2008), Poznań (Pawłowski 1993, as cited by Mazgajska 1996), where 
Table 1. The number of amphibian species, abundance of individuals $(n)$ and domination $(\%)$ in the whole community in relation to the location of studied water bodies. Location: 1 - concentrated buildings, 2 - scattered, low buildings, 3 - city parks, 4 - suburban forests, 6 - suburban areas influenced by human activity, 7 - suburban areas uninfluenced by human activity, 8 - gardens, 9 - areas between forest habitat and open habitat. $N-$ number of water bodies, $\mathrm{n}$ - estimated number of individuals. "Green frogs" (Rana esculenta complex) always include two species: pool frog and edible frog.

\begin{tabular}{|c|c|c|c|c|c|c|c|c|c|c|c|c|c|c|c|c|}
\hline \multirow{3}{*}{ Species } & \multicolumn{16}{|c|}{ Location of small water bodies } \\
\hline & \multicolumn{2}{|c|}{$\begin{array}{c}1 \\
(\mathrm{~N}=3)\end{array}$} & \multicolumn{2}{|c|}{$\begin{array}{c}2 \\
(\mathrm{~N}=25)\end{array}$} & \multicolumn{2}{|c|}{$\begin{array}{c}3 \\
(\mathrm{~N}=6)\end{array}$} & \multicolumn{2}{|c|}{$\begin{array}{c}4 \\
(N=10)\end{array}$} & \multicolumn{2}{|c|}{$\begin{array}{c}5 \\
(\mathrm{~N}=25)\end{array}$} & \multicolumn{2}{|c|}{$\begin{array}{c}7 \\
(\mathrm{~N}=113)\end{array}$} & \multicolumn{2}{|c|}{$\begin{array}{c}8 \\
(\mathrm{~N}=8)\end{array}$} & \multicolumn{2}{|c|}{$\begin{array}{c}9 \\
(\mathrm{~N}=10)\end{array}$} \\
\hline & $\mathrm{n}$ & $\%$ & $\mathrm{n}$ & $\%$ & $\mathrm{n}$ & $\%$ & $\mathrm{n}$ & $\%$ & $\mathrm{n}$ & $\%$ & $\mathrm{n}$ & ${ }_{0}^{0} 0$ & $\mathrm{n}$ & $\%$ & $\mathrm{n}$ & ${ }_{0}^{0}{ }_{0}$ \\
\hline \multicolumn{17}{|l|}{1997} \\
\hline Bombina bombina & 3 & 3.0 & 35 & 4.3 & & & 8 & 1.1 & 76 & 2.7 & 166 & 1.5 & & & & \\
\hline Bufo bufo & 6 & 6.1 & 80 & 9.8 & 120 & 21.4 & 34 & 4.8 & 780 & 27.6 & 1968 & 18.1 & 243 & 27.7 & 23 & 1.4 \\
\hline Bufo viridis & 8 & 8.1 & & & 30 & 5.3 & & & & & 77 & 0.7 & & & & \\
\hline Hyla arborea & & & 30 & 3.7 & & & 30 & 4.3 & 8 & 0.3 & 104 & 1.0 & & & 11 & 0.7 \\
\hline Pelobates fuscus & & & 9 & 1.1 & & & 3 & 0.4 & 11 & 0.4 & 77 & 0.7 & & & 38 & 2.3 \\
\hline Rana anvalis & 3 & 3.0 & 22 & 2.7 & & & 3 & 0.4 & 59 & 2.1 & 635 & 5.9 & & & 1140 & 70.0 \\
\hline Rana temporaria & & 23.2 & 376 & 46.1 & 60 & 10.7 & 315 & 44.8 & 836 & 29.6 & 3239 & 29.9 & 154 & 17.5 & 128 & 7.9 \\
\hline Rana esculenta complex & 56 & 56.5 & 264 & 32.4 & 306 & 54.5 & 292 & 41.6 & 1045 & 36.9 & 4429 & 40.8 & 421 & 47.9 & 285 & 17.5 \\
\hline Triturus cristatus & & & & & & & & & & & 92 & 0.8 & & & & \\
\hline Triturus vulgaris & & & & & 45 & 8.0 & 18 & 2.6 & 14 & 0.5 & 60 & 0.6 & 60 & 6.8 & 3 & 0.2 \\
\hline $\begin{array}{r}\text { Total } \\
\end{array}$ & 99 & 100.0 & 816 & 100.0 & 561 & 100.0 & 703 & 100.0 & 2829 & 100.0 & 10847 & 100.0 & 878 & 100.0 & 1628 & 100.0 \\
\hline Total number of species & \multicolumn{2}{|c|}{7} & \multicolumn{2}{|c|}{8} & \multicolumn{2}{|c|}{6} & \multicolumn{2}{|c|}{9} & \multicolumn{2}{|c|}{9} & \multicolumn{2}{|c|}{11} & \multicolumn{2}{|c|}{5} & \multicolumn{2}{|c|}{8} \\
\hline \multicolumn{17}{|l|}{1998} \\
\hline Bombina bombina & \multirow{7}{*}{24} & \multirow{7}{*}{25.3} & 3 & 0.2 & & & \multirow{4}{*}{30} & \multirow{4}{*}{1.2} & \multirow{5}{*}{$\begin{array}{c}18 \\
122\end{array}$} & \multirow{5}{*}{$\begin{array}{c}4.1 \\
27.5\end{array}$} & 67 & 0.4 & \multirow{4}{*}{362} & & & \\
\hline Bufo bufo & & & 130 & 7.4 & & & & & & & 526 & 3.2 & & 24.9 & 8 & 4.9 \\
\hline Bufo viridis & & & 26 & 1.5 & & & & & & & 65 & 0.4 & & & & \\
\hline Hyla arborea & & & & & & & & & & & 130 & 0.8 & & & & \\
\hline Pelobates fuscus & & & 11 & 0.6 & & & 3 & 0.1 & & & 109 & 0.7 & 8 & 0.5 & & \\
\hline Rana anvalis & & & 427 & 24.4 & & & 2010 & 78.7 & 50 & 11.3 & 7956 & 47.9 & 850 & 58.4 & 61 & 37.4 \\
\hline Rana temporaria & & & 561 & 32.1 & & & 264 & 10.3 & 51 & 11.5 & 5283 & 31.8 & 132 & 9.1 & 84 & 51.5 \\
\hline Rana esculenta complex & 68 & 71.5 & 563 & 32.2 & 241 & 93.1 & 248 & 9.7 & 165 & 37.2 & 2416 & 14.5 & 104 & 7.1 & 10 & 6.1 \\
\hline Triturus vulgaris & 3 & 3.2 & 26 & 1.5 & 18 & 6.9 & 38 & 8.6 & & & 70 & 0.4 & & & & \\
\hline Total & 95 & 100.0 & 1747 & 100.0 & 259 & 100.0 & 2555 & 100.0 & 444 & 100.0 & 16622 & 100.0 & 1456 & 100.0 & 163 & 100.0 \\
\hline Total number of species & & 4 & & & & & & & & & 1 & & & & & 5 \\
\hline
\end{tabular}


Table 2. The number of the amphibian species in relation to the location of water bodies. $\mathrm{N}$ - number of water bodies studied.

\begin{tabular}{|l|c|c|c|c|c|c|c|c|}
\hline \multirow{2}{*}{\multicolumn{1}{|c|}{ Location }} & \multicolumn{7}{|c|}{ Number of amphibian species } \\
\cline { 2 - 9 } & \multicolumn{7}{|c|}{ All small water bodies } & \multicolumn{3}{c|}{ Small water bodies with amphibians } \\
\cline { 2 - 9 } & $\mathrm{N}$ & Median & $\begin{array}{c}\text { Average } \\
\pm \text { SD }\end{array}$ & Range & $\mathrm{N}$ & Median & $\begin{array}{c}\text { Average } \\
\pm \text { SD }\end{array}$ & Range \\
\hline Concentrated buildings & 3 & 3.0 & $3.67 \pm 1.15$ & $3-5$ & 3 & 3.0 & $3.67 \pm 1.15$ & $3-5$ \\
Scattered, low buildings & 25 & 1.0 & $1.76 \pm 1.83$ & $0-6$ & 19 & 2.0 & $2.32 \pm 1.77$ & $1-6$ \\
City parks & 6 & 2.0 & $2.00 \pm 1.26$ & $0-3$ & 5 & 3.0 & $2.40 \pm 0.89$ & $1-3$ \\
Suburban forests & 10 & 2.0 & $2.40 \pm 2.12$ & $0-6$ & 8 & 3.0 & $3.00 \pm 1.93$ & $1-6$ \\
Suburban areas influen- & 25 & 2.0 & $2.04 \pm 1.81$ & $0-6$ & 18 & 3.0 & $2.83 \pm 1.50$ & $1-6$ \\
ced by human activity & 113 & 2.0 & $2.56 \pm 1.75$ & $0-9$ & 101 & 3.0 & $2.86 \pm 1.59$ & $1-9$ \\
Suburban areas uninfluen- \\
ced by human activity
\end{tabular}

the "green frogs" were inclusive of the marsh frog Rana ridibunda Pallas, 1771 and in Bialystok (Siwak et al. 2000) where the Bufo calamita (Laurenti, 1768), a species having no breeding sites in Olsztyn, was found. A similar species composition was determined in Wroclaw (Kierzkowski \& Ogielska 2001), but without the presence of the crested newt. Significant variations were noted in the species composition of amphibian communities in Kraków, Gniezno and Poznań. The investigated habitats were colonized by the marsh frog, but were marked by an absence of the tree frog, an absence of the common spadefoot in Kraków, and an absence of the crested newt in Gniezno (Juszczyk 1989, Guzik et al. 1996, Adamiak 2008). Significantly different batrachofauna was observed in the water bodies of Zielona Góra (Najbar et al. 2005), which were colonized, by the alpine newt Triturus alpestris (Laurenti, 1768) and the marsh frog, in the absence of the fire-bellied toad and the tree frog.

The above differences in species composition relative to Olsztyn can be attributed to the geographic location of marsh frog and alpine newt populations (Glowaciński \& Rafinski 2003), as well as differences in the extinction rate of habitats colonized by three species that are most sensitive to urbanization: the natterjack toad, the tree frog and the fire-bellied toad.

From among the species reported in the Olsztyn Lakeland, the natterjack toad was not found in Olsztyn. The nearest breeding site of the species was observed around $5 \mathrm{~km}$ east of the city`s limits. The marsh frog, which has not been observed in the Masurian Lakeland to date (Glowaciński \& Rafinski 2003), was not reported during the period of this study. The nearest marsh frog site was found in the Ilawa Lakeland (Glowaciński \& Rafiński 2003) and in the valley of the Pisa River in the Masurian and Kurpie Plain (J. J. Nowakowski - unpublished data).

Except for Bialystok and (probably) Poznan, where the natterjack toad was observed in small numbers, the species was not found in the remaining cities. Although the 
natterjack toad has been spotted in suburban areas, it does not have any breeding sites in Olsztyn. Small populations of the discussed taxon were noted in Zielona Góra in the early 1970s, and the species disappeared from the city in 1979 (Najbar et al. 2005). The above could be due to strong urban pressure in open areas and changes in the city's hydrographic network. The natterjack toad is one of Polish amphibian species that is most adapted to live in a terrestrial habitat. It colonizes xerothermic habitats and grasslands with loose, sandy soils. The species reproduces mostly in intermittent, shallow water bodies, small hollows without stream outflow, puddles and bog-springs (Juszczyk 1987). In urban areas, open habitats undergo rapid transformation due to intensive development, they are isolated by road networks, and they are adversely affected by changes in the soil structure. The construction of sewer systems that rapidly drain rain water leads to the extinction of seasonal water bodies. Tadpoles of the natterjack toad develop over a period of two months, therefore the drying up of intermittent water bodies containing spawns and tadpoles contributes to a rapid drop in the local population. Urban pressure could be the main reason for the disappearance of the analyzed species from large cities.

The disappearance of water-logged areas, a drop in the water level, the degradation of meadows and "clean up" activities along the banks of urban water bodies are the main anthropogenic factors responsible for the extinction of habitats of the tree frog and the fire-bellied toad in cities. The tree frog inhabits areas with a high groundwater level, and it breeds in water bodies densely overgrown with aquatic vegetation. The natural habitats of the fire-bellied toad are shallow floodplains with dense vegetation cover (Juszczyk 1987).

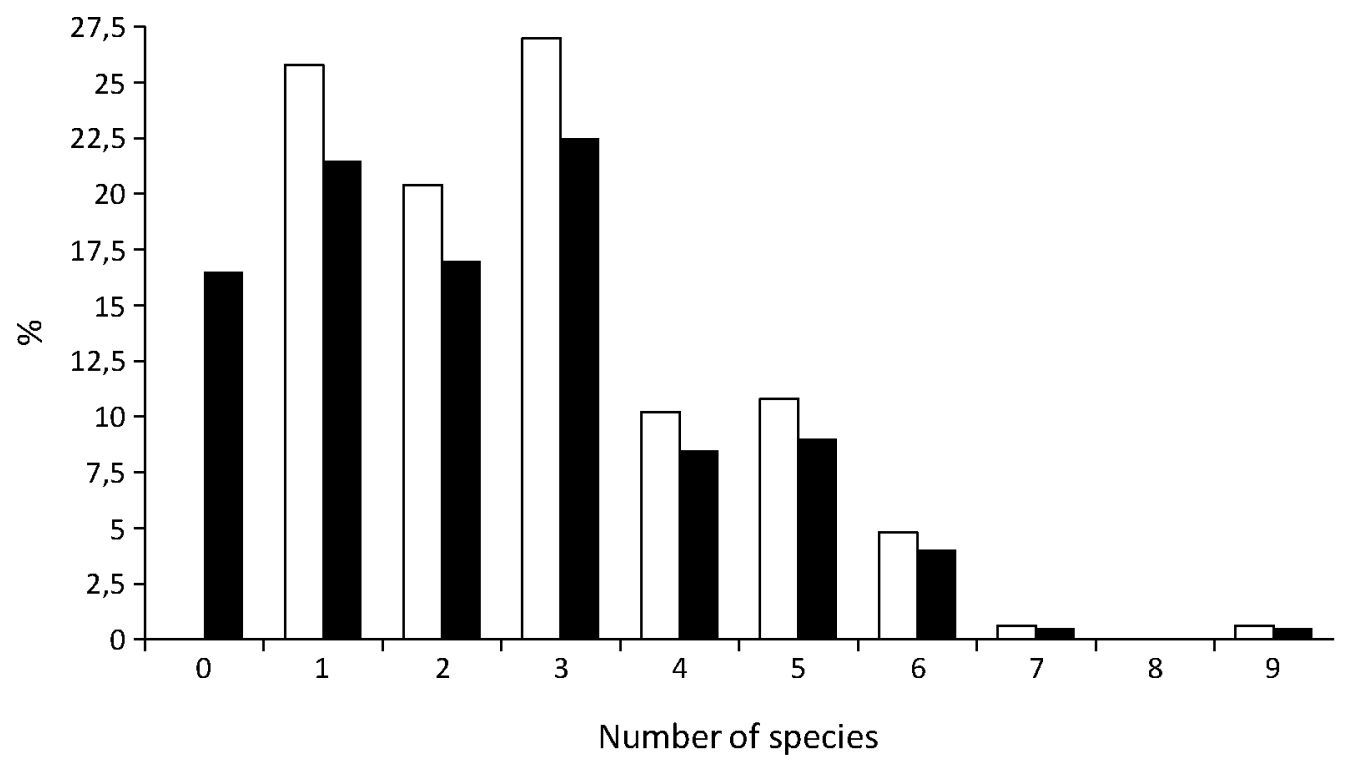

Fig. 3. Number of species distribution in small water bodies in Olsztyn. 


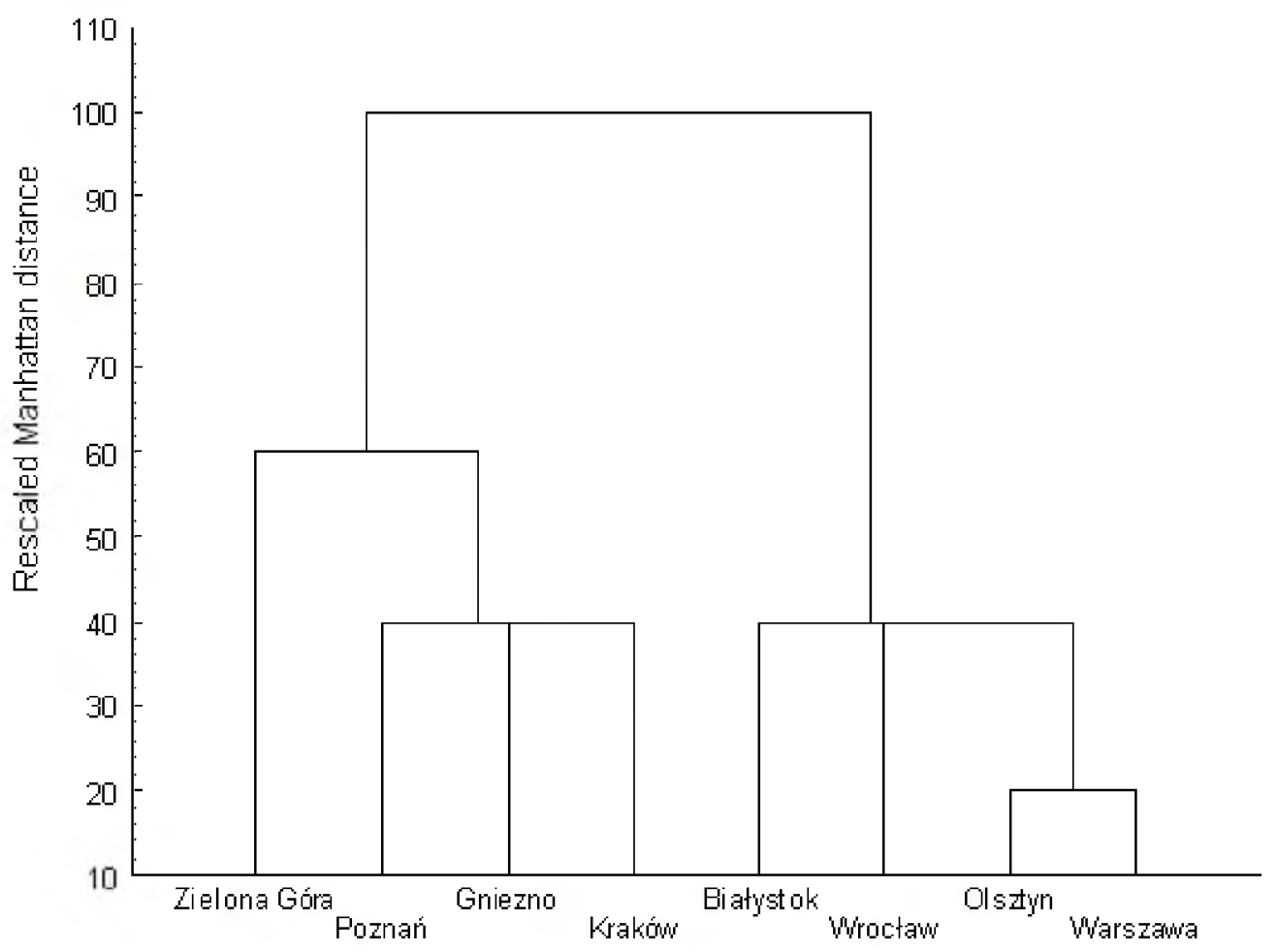

Fig. 4. Similarity of amphibian community structure of the big Polish cities.

Similarly to Warszawa (Mazgajska 1996) and Wroclaw (Kierzkowski \& Ogielska 2001), green frogs were the dominant taxon in the quantitative structure of amphibian communities in Olsztyn. Green frogs were observed in all identified types of aquatic ecosystems, both in the suburban zone and in the densely developed city center. The edible frog was determined in most water bodies (Nowakowski et al. 2008). In the authors 'opinion, the edible frog is one of the species most resistant to the adverse effects of urbanization. Characterized by a high degree of ecological flexibility, this eurybiontic taxon quickly colonizes new ecosystems, it is least susceptible to anthropogenic pressure and shows the highest level of resistance to changes in the agricultural landscape (Berger \& Rybacki 1998, Glowaciński \& Rafiński 2003).

In comparison with other cities, the amphibian communities of Olsztyn were characterized by a much higher total abundance even if the noted results account only for the populations noted in small water bodies (Nowakowski et al. 1998) and disregard large populations breeding in the littoral zones of lakes situated within city limits (Nowakowski et al. 2008) that were not an object of this study.

Significant differences in the species and quantitative composition of amphibians were observed in individual water bodies and in the analyzed types of water bodies in Olsztyn's urban environment. Regardless of the type of the surrounding area, most 
water bodies were colonized by two to three amphibian species. Aquatic habitats with a higher number of species had less than a $30 \%$ share of the total number of water bodies inhabited by amphibians. The noted differences resulted mainly from the size of the water body and the diversity of the littoral zone which provided a supportive environment for the growth and reproduction of a given species. Species richness was affected by the size of the water body, the length of the shore line and the length of the shore line overgrown by helophytes in case of birds (Nowakowski et al. 2001a). The above correlations determine the positive effect that the size and the degree of isolation of a "habitat island" have on species diversity (Mac Arthur \& Wilson 1967). Such correlations were also pointed out by Minton (1968) who argued that the low number of amphibian species in municipal parks was due to the parks small size and a high degree of isolation. The noted variations in species abundance and the size of amphibian populations inhabiting water bodies may also follow from the combined effect of other factors, including different habitat preferences, the avoidance or consequences of interspecific competition, predation and urban pressure in the areas surrounding water bodies.

Single taxa were more frequently observed in water bodies situated in areas with dispersed, low-rise buildings and in allotment gardens. The above results not only from intensified urban pressure, which is rarely encountered in the allotment zone, but also from human activity and the anthropogenic transformation of aquatic ecosystems. Mazgajska (1996) and Majewski \& Nowakowski (2001) suggested that growing urbanization in areas surrounding water bodies impoverishes the species structure of amphibian communities and supports single species domination.

Nowakowski et al. $(2001 \mathrm{~b}, 2008)$ have demonstrated that the community of six amphibian species in Olsztyn's allotment gardens was clearly dominated by the common toad and was characterized by the lowest species diversity (Shannon index $\mathrm{H}^{\circ}=1.54$ ). Significant differences were noted in comparison with the amphibian communities inhabiting water bodies in residential zones $\left(\mathrm{H}^{\prime}=2.18\right)$ and the suburban zone $\left(\mathrm{H}^{\prime}=2.46\right)$. The species structure of amphibians in allotment gardens was similar to that noted in residential zones (Soerensen index So $=80.0 \%$ ), while the domination structure of the compared communities was different (Renkonen index RE $=46.98 \%$ ). Both communities were characterized by a very low share of the moor frog, an absence of the crested newt and much lower occurrence frequency of the fire-bellied toad and the common spadefoot in comparison with Olsztyn's suburban habitats.

The lower species diversity in allotment gardens and residential districts in comparison with suburban areas (wooded and open areas) can be attributed to the specific features of different aquatic habitats. In suburban areas, a vast number of intermittent water bodies are formed in early spring, and they are the breeding site of the common frog, the fire-bellied toad and the common spadefoot. Water bodies without stream outflow in suburban barren lands and forests were also the habitat of the crested newt. A nearly complete absence of seasonal water bodies was noted in allotment gardens and residential estates. Kierzkowski \& Ogielska (2001) also observed a higher level of amphibian species diversity in the catchment areas of Odra and Olawa rivers in Wroclaw in comparison with developed areas where the number of amphibian species decreased 
from the 1980s. The key factors responsible for the drop in species diversity in allotment gardens include water and environmental pollution with fertilizers and herbicides as well as human activity.

Artificial fertilizers and herbicides reach aquatic habitats with runoff water, contributing to the contamination of amphibian eggs and larvae (Cooke 1971). Rain water washes away deposited contaminants which comprise vast quantities of chlorides, sulfates and hydrocarbons in urban areas (Zimny 2005). In Warszawa, earthworms (Lumbricidae) colonizing lawns in the vicinity of roads contained higher quantities of heavy metals than the earthworms inhabiting parks (Zimny 2005). Chemical substances are also likely to accumulate in the soil of the investigated allotment gardens, thus affecting the food chain. Amphibian skin is permeable to water and gas, and as predators, amphibians accumulate toxic chemical substances ingested with food. The above has an adverse effect on their survival and reproduction, and it could explain the relatively small size of amphibian populations in this environment.

Bishop et al . (2000) found that amphibians reproducing in man-made retention ponds were characterized by lower mating success. In comparison with natural habitats, those ecosystems were colonized by fewer species due to the absence of aquatic vegetation, chemical contamination of water and blue-green algal blooms. The abundance of amphibians in water bodies is also determined by the water $\mathrm{pH}$. Except for the pool frog, which inhabits peatlands with water $\mathrm{pH}$ of 5 (Heym 1974), the remaining frog species and the natterjack toad tend to avoid acidic habitats (pH 4-5) (Beebee \& Griffin 1977, Strijbosch 1979, Beebee 1983). The above findings were not validated by the results of a study investigating the environmental preferences of the common frog in northern England which showed no correlations between the water $\mathrm{pH}$ and the presence of the analyzed species (Aston et al. 1987). The acid rain effect in urban areas may also contribute significantly to environmental pollution due to the presence of extensive transport networks and local physiographic features, leading to variations in amphibian populations regardless of the type of the water body. Precipitation, including snow cover and fog, may contain nitrogen compounds, in particularly transport-related substances. According to Rouse et al. (1999), high concentrations of those compounds in urban surface waters may deliver a toxic effect.

Amphibians are also subject to various global threats that can reduce their populations, including the depletion of the ozone layer which increases surface UV levels and causes global warming. According to Beebee (1995), climate change can lead to the earlier onset of mating in species that normally mate at certain intervals. The above affects the availability of food resources and intensifies interspecific competition. Similar effects are noted in the urban environment where the average annual temperatures are higher in comparison with the surrounding areas (Zimny 2005). The above could lead to the domination of a small number of species in selected water bodies, lower mating success, accelerated metamorphosis, smaller body size and lower survival rates.

In view of the growing urban pressure on amphibian communities, the highest decrease in species diversity should be expected in water bodies situated in densely developed municipal areas. The results of this study do not fully validate this assumption. 
The above could be due to the small size of the analyzed sample (only three water reservoirs in a densely developed residential estate), but the noted results most likely reflect the fact that the studied aquatic habitats became part of residential districts relatively recently (two-three years ago). This could suggest that amphibians avoid areas marked by a high degree of human intervention, but it should also be noted that environmental changes and changes in amphibian abundance will be induced by the new ecological factor with a certain delay. Differences in the structure of amphibian communities result not only from the location of water bodies relative to urban areas and the specific features of their direct surroundings, but also from the duration of the aquatic ecosystem 's isolation from natural habitats. The history of a water body and its surroundings and the degree of isolation could significantly affect the species diversity of the local fauna. The above factors could obscure the effect of urban pressure on amphibian communities in Olsztyn. The city comprises a vast network of ecological corridors between built-up areas (Nowakowski \& Dulisz 1998) potentially allowing amphibians to migrate to zones subjected to human pressure.

\section{REFFERENCES}

ADAмtaK W. 2008. Sklad gatunkowy i liczba stanowisk plazów na terenie miasta Gniezna. In: ZAMACHOWSKI W. (ed.). Biologia plazów i gadów - ochrona herpetofauny. IX Ogólnopolska Konferencja Herpetologiczna. 22-23.09.2008. Kraków. pp. 15-18. Wydawnictwo Naukowe Akademii Pedagogicznej. Kraków. 188 pp.

Alford R. A. \& Richards J. 1999. Global amphibian declines: a problem in applied ecology.

Annual Review of Ecology and Systematics 30: 133-165.

AnTROP M. 2004. Landscape change and the urbanization process in Europe. Landscape and Urban Plannning 67: 9-26.

Aston R. J., Beatte R. C. \& Milner A. G. P. 1987. Characteristics of spawning sites of the common frog (Rana temporaria) with particular reference to acidity. J. Zool. 213: 233-242.

BEEBEE T. J. C. 1983. Habitat selection by amphibians across an agricultural land - heathland transect in Britain. Biological Conservation 27: 111-124.

BEEBEE T. J. C. 1995. Amphibian breeding and climate. Nature 374: 219-220.

BEEBEE T. J. C. 1996. Ecology and conservation of amphibians. Chapman \& Hall. London. 214 pp.

BeEBeE T. J. C. \& GRIFFIN J. R. 1977. A preliminary investigation into Natterjack Toad (Bufo calamita) breeding site characteristics in Britain. J. Zool. 181: 341-350.

BeEBeE T. J. C. \& Griffiths R. A. 2005. The amphibian decline crisis: A watershed for conservation biology? Biological Conservation 125: 271-285.

BERgER L. \& R YBACKi M. 1998. Composition and ecology of water frog populations in agricultural landscape in Wielkopolska (Central Poland). Biol. Bull. Poznań. Zoology 35: 103-111.

Bishop C. A.. Struger J., Barton D. R., Shirose L. J.. Dunn L.. Lang A. L. \& Shepard D. 2000. Contamination and wildlife communities in stormwater detention ponds in Guelph and the Greater Toronto Area. Ontario. 1997 and 1998 Part I - Wildlife communities. Water Quality Research Journal Canada 35: 399-435.

BlaR R. B. 1996. Land use and avian species diversity along an urban gradient. Ecological Application 6: 506-519. 
Blaustein A. R.. Edmond B.. Kiesecker J. M., Beatty J. J. \& Hokit D. G. 1995. Ambient ultraviolet radiation causes mortality in salamander eggs. Ecological Application 5: 740-743.

Blaustein A. R., Romansic J. M., Kiesecker J. M. \& Hatch A. C. 2003. Ultraviolet radiation, toxic chemicals and amphibian population declines. Diversity and Distributions 9: 123-140.

BRADFORD D. F. 1989. Allotopic distribution of native frogs and introduced fishes in high Sierra Nevada lakes of California: implications of the negative effect of fish introduction. Copeia 1989: 775-778.

Breuste J., Feldan H. \& Uhlman O. (eds). 1998. Urban Ecology. Springer Verlag. Berlin. 714 pp. Brooks T. M., Mittermeter R. A.. Mittermeier C. G.. Da Fonsenca G. A. B.. Rylands A. B.. Konstant W. R., Flick P., Pilgrim J., Oldfield S., Magin G. \& Hıton-Taylor C. 2002. Habitat loss and extinction in the hotspots of biodiversity. Conservation Biology 16: 1523-1739.

Collins J. P. \& Storfer A. 2003. Global amphibian declines: sorting the hypotheses. Diversity and Distributions 9: 89-98.

Cooke A. S. 1971. Selective predation by newts on frog tadpoles treated with DDT. Nature 229: 275-276.

Corn P. S. 2000. Amphibian declines: review of some current hypotheses. In: Sparling D. W., Bishop C. A. \& Linder G. (eds). Ecotoxicology of amphibians and reptiles. pp. 663-696. Society of Environmental Toxicology and Chemistry, Pensacola. Florida. 904 pp.

Corn P. S. 2005. Climate change and amphibians. Animal Biodiversity and Conservation 28: $59-67$.

Cushman S. A. 2006. Effects of habitat loss and fragmentation on amphibians: a review and prospectus. Biological Conservation 128: 231-240.

Daszak P. 2003. Infectious disease and amphibian population declines. Diversity and Distributions 9: 141-150.

DiCKMAN C. R. 1987. Habitat fragmentation and vertebrate species richness in an urban environment. Journal of Applied Ecology 24: 337-351.

Fisher R. N. \& Shaffer H. B. 1996. The decline of amphibians in California's Great Central Valley. Conservation Biology 10: 1387-1397.

GŁowaciński Z. \& Rafinski J. (eds) 2003. Atlas of the amphibians and reptiles of Poland. Status - Distribution - Conservation. Biblioteka Monitoringu Środowiska. Warszawa - Kraków. 156 pp. [In Polish with English summary]

GreEn D. M. (ed.). 1995. Amphibians in decline. Canadian studies of a global problem. Society for the Study of Amphibians and Reptiles, Saint Louis Missouri. 351 pp.

Guzik M., Schimscheiner L., Zakrzewski M., Zamachowski W. \& Zyśk A. 1996. Herpetofauna of Cracow city. Studia Ośrodka Dokumentacji Fizjograficznej 24: 247-262. [In Polish with English summary]

Hamer A. J. \& McDonneli M. J. 2008. Amphibian ecology and conservation in the urbanising world: A review. Biological Conservation 141: 2432-449.

HEYM W. D. 1974. Studien zur Verbreitung. Ökologie und Ethologie der Grünfrösche in der mittleren und nördlichen Niederlausitz. Mitteilungen aus dem zoologischen Museum in Berlin 50: $263-285$.

Houlahan J. E., Findlay C. S., Schmitt B. R., Meyer A. H. \& Kuzmin S. L. 2000. Quantitative evidence for global amphibian population declines. Nature 404: 752-755.

JoHnSON B. 1992. Habitat loss and declining amphibian populations. In: Bishop C. A. \& K. E. Pettit (eds). Declines in Canadian Amphibian Populations: Designing a National Monitoring Strategy. pp. 71-75. Canadian Wildlife Service. Occasional Paper 76. Ottawa. Ontario. Kanada, 120 pp. 
Juszczyk W. 1987. Plazy i gady krajowe. Vol. 2. Państwowe Wydawnictwo Naukowe, Warszawa, 384 pp.

Juszczyk W. 1989. Plazy i gady miasta Krakowa w latach 1922-1979. Przegląd Zoologiczny 33: 373-381.

Karolewski M. A. 1981. Specyfika i status ekologiczny miasta. Wiadomości Ekologiczne 27: 3-35.

Kierzkowski P. \& Ogielska M. 2001. [Amphibians in the city of Wroclaw, Poland]. Chrońmy Przyrodę Ojczystą 57: 65-80. [In Polish with English summary]

Kiesecker J. M. \& Blaustein A. R. 1995. Synergism between UV-B radiation and a pathogen magnifies amphibian embryo mortality in nature. Proceedings of the National Academy of Sciences. USA 92: 11049-11052.

Kondracki J. 2002. Geografia regionalna Polski. Wydawnictwo Naukowe PWN. Warszawa. 450 pp.

Krai B.. Pellantova J. \& Kokes J. 1983 Amphibian and reptiles of the Brno urban agglomeration. Folia zoologica 32: 51-66.

KRZYŚCIAK-Kosinska R. 2000. What threatens amphibians at dawn of the new millennium. Wiadomości Ekologiczne 46: 115-126. [in Polish with English summary]

Lannoo M. J.. Lang K.. Waltz T. \& Phillips G. S. 1994. An altered amphibian assemblage: Dickinson County. Iowa. 70 years after Frank Blanchard's survey. American Midland Naturalist 131: 311-319.

Laurance W. F. McDonald K. R. \& Speare R. 1996. Epidemic and catastrophic decline of Australian rain forest frogs. Conservation Biology 10: 406-413.

Long L. E., Saylor L. S. \& Soule M. E. 1995. A pH/UV-B synergism in amphibians. Conservation Biology 9: 1301-1303.

LUNIAK M. 1998. Synurbization - the adjustment of animals to urban development. In: BARCZAK T. \& Indykiewicz P. (eds), Fauna Miast - Urban fauna, pp. 13-19.Wyd. ATR, Bydgoszcz. 263 pp. [in Polish with English summary]

MacArthur R. H. \& Wilson E. O. 1967. The theory of island geography. Princeton. University Press. 203 pp.

Majewski T. \& Nowakowski J. J. 2001. The influence of urban environment on the structure and season dynamic of numbers of amphibian communities in Olsztyn town. In: IND YKIEwICz P.. BarczaK T. \& KaCzorowski G. (eds). Bioróżnorodność i ekologia populacji zwierzęcych w środowiskach zurbanizowanych. WYD. NICE, Bydgoszcz. pp. 283-287. [in Polish with English summary]

MARKowski J. 1997. Specyfika synurbijnych populacji zwierząt. In: KuRnatowsKa A. (ed.). Ekologia. Jej związki z różnymi dziedzinami wiedzy, pp. 143-170. PWN, Warszawa-Łódź, 332 pp.

Marzluff J. M. 2001. Worldwide urbanization and its effects on birds. In: Marzluff J. M.. Bowman R. \& Donnelly R. (eds), Avian ecology in an urbanizing world, pp. 19-47. Kluwer, Norwell, 608 pp.

MazGajska J. 1996. Distribution of amphibians in urban water bodies (Warsaw agglomeration. Poland). Ekologia Polska 44: 245-257.

Mazgajska J. 1998. The studies on batrachofauna in Warsaw in 1992-1994. In: Barczak T. \& INDYKiEwicz P. (eds). Fauna Miast - Urban fauna. pp. 227-236. Akademia Techniczno Rolnicza, Bydgoszcz, 263 pp. [In Polish with English summary]

MAZGAJSKA J. 2008. Zmiany składu gatunkowego batrachofauny Warszawy w ostatnich piętnastu latach. w związku z przeksztalceniami środowisk rozrodczych. In: ZAMACHOwSKI W. (ed.). Biologia plazów i gadów - ochrona herpetofauny. IX Ogólnopolska Konferencja Herpeto- 
logiczna, 22-23.09.2008, Kraków, pp. 66-67. Wydawnictwo Naukowe Akademii Pedagogicznej. Kraków. 188 pp.

MCKINNEy M. L. 2002. Urbanization. biodiversity, and conservation. Bioscience 52: 883-90.

Milier J. R. \& Hobbs R. J. 2002. Conservation where people live and work. Conservation Biology 16: $330-337$.

Milis G. S., Dunning J. B. \& Bates J. M. 1989. Effects of urbanization on breeding bird community structure in southwestern desert habitats. Condor 91: 416-428.

Minton S. A. JR. 1968. The fate of amphibians and reptiles in a suburban area. Journal of Herpetology 2: 113-116.

Najbar B.. Szuszkiewicz E. \& Pietruszka T. 2005. Amphibia in Zielona Góra and the disappearance of their sites located within the administrative borders of the town it the years 1974-2004. Przegląd Zoologiczny 49: 155-166. [In Polish with English summary]

Nowakowski J. J. \& Dulisz B. 1998. Ornithological evaluation as a basis for new project of ecological corridors using in Olsztyn city. In: BARCZAK T. \& INDYKIEWICZ P. (eds), Fauna Miast - Urban fauna. pp. 195-204. Wyd. ATR. Bydgoszcz. 263 pp. [in Polish with English summary]

Nowakowski J. J., Górski A. \& Lewandowski K. 2001A. Birds of small water bodies in Olsztyn city (N-E Poland). In: Indykiewicz P.. Barczak T. \& Kaczorowski G. (eds). Bioróżnorodność i ekologia populacji zwierzęcych w środowiskach zurbanizowanych. pp. 184-191. WYD. NICE. Bydgoszcz. [in Polish with English summary]

Nowakowski J. J.. Górski A. \& Lewandowski K. 2001B. Impact of surroundings of water reservoirs on qualitative and quantitative structure of amphibian communities of small water bodies of lsztyn city.. In: Ind Ykiewicz P., Barczak T. \& KaCzorowski G. (eds). Bioróżnorodność i ekologia populacji zwierzęcych w środowiskach zurbanizowanych. WYD. NICE. BydgoSzcz, pp. 288-297. [in Polish with English summary]

Nowakowski J. J. Górski A.. Lewandowski K. \& Dulisz B. 2008. Amphibians and reptiles of Olsztyn city. In: Indykiewicz P., JERzAK L. \& Barczak T. (eds). Fauna Miast - Ochronić różnorodność biotyczną w miastach. pp. 151-167, SAR „Pomorze”. Bydgoszcz. [in Polish with English summary]

Nowakowski J. J., Górski A., Lewandowski K., Dulisz B., Wasilewska B., Mioduszewska U. \& Pergol S. 1998. The amphibians of small water bodies in Olsztyn city (N-E Poland). In: Barczak T. \& Indykinwicz P. (eds), Fauna Miast - Urban fauna. pp. 221-226. Wyd. ATR. Bydgoszcz, 263 pp. [in Polish with English summary]

Ovaska K., Davis T. M. \& Flamarique I. N. 1997. Hatching success and larval survival of the frogs Hvla regilla and Rana aurora under ambient and artificially enhanced solar ultraviolet radiation. Canadian Journal of Zoology 75: 1081-1088.

Pasmans F., Mutschmann F., Haliday T. \& Zwart P. 2006. Amphibian decline: the urgent need for amphibian research in Europe. Veterinary Journal 171: 18-19.

PAWŁowski A. 1993. Plazy miasta Poznania. MSc. thesis. Zaklad Zoologii Ogólnej Uniwersytet A. Mickiewicza i Zakład Badań Środowiska Rolniczego i Leśnego PAN, Poznań. 82 pp.

ROHR J. R. \& RAFFEL T. R. 2010. Linking global climate and temperature variability to widespread amphibian declines putatively caused by disease. Proceedings of the National Academy of Sciences 107: 8269-8274.

Rouse J. D., Bishop Ch. A. \& Struger J. 1999. Nitrogen pollution: an assessment of its threat to amphibian survival. Environmental Health Perspectives 107: 799-803.

Stwak P., Kossakowski R. \& Chętnicki W. 2000. Amphibians of Białystok. In: Latowski K. (ed.). Studia Biologiczne. pp. 117-121. Bogucki Wydawnictwo Naukowe S.C.. Poznań. 173 pp. [In Polish with English summary] 
Sparling D. W., Linder G. \& Bishop C. A. 2000. Ecotoxicology of amphibians and reptiles. Society of Environmental Toxicology and Chemistry. Pensacola. Florida. 904 pp.

Stuart S. N., Chanson J. S., Cox N. A., Young B. E., Rodrigues A. S. L., Fischman D. L. \& Walier R. W. 2004. Status and trends of amphibian declines and extinctions worldwide. Science 306: 1783-1786.

Stopczyński M., Zielníski P. \& Wotcerchowski Z. 2004. Plazy Lasu Łagiewnickiego w Łodzi. Chrońmy Przy rodę Ojczystą 60: 5-31.

Stridiosch H. 1979. Habitat selection of amphibians during their aquatic phase. Oikos 33 : $363-372$.

Sukope H. \& Werner P. 1982. Nature in cities. Council of Europe. Strasbourg. 54 pp.

Vitousek P. M.. Mooney H. A.. Lubchenco J. \& Melilio J. M. 1997. Human domination of the Earth's ecosystems. Science 277: 494-499.

WAKE D. B. 2007. Climate change implicated in amphibian and lizard declines. Proceedings of the National Academy of Sciences 104: 8201-8202.

ZIMNY H. 2005. Ekologia miasta. Agencja Reklamowo-Wydawnicza A. Grzegorczyk. Warszawa. $233 \mathrm{pp}$.

\section{STRESZCZENIE}

\section{[Plazy Olsztyna]}

Wspólcześnie wielu badaczy zwraca uwagę na liczne zagrożenia oraz globalny spadek różnorodności gatunkowej i liczebności populacji batrachofauny, a wśród ważnych przyczyn, wymienia się m.in. degradację środowisk wskutek urbanizacji. Środowiskowe uwarunkowania skladu gatunkowego i ilościowego zespolów plazów miast sa niedostatecznie poznane, dlatego też celem pracy byla charakterystyka skladu gatunkowego i ilościowego zespolów płazów drobnych zbiorników wodnych Olsztyna oraz ocena wplywu antropopresji na ich strukturę i liczebność. Badania przeprowadzono w granicach administracyjnych Olsztyna $\left(87,9 \mathrm{~km}^{2}\right)$, polożonego w centralnej części Pojezierza Olsztyńskiego w latach 1997-1998. Inwentaryzację przeprowadzono w 200 drobnych zbiornikach wodnych, stalych i okresowych o łacznej powierzchni 114,368 ha (1,3\% obszaru miasta). Wydzielono następujące kategorie zbiorników: 1 - zbiorniki zlokalizowane w gęstej zabudowie ( 3 zbiorniki; 1,5\%), 2 - zbiorniki zlokalizowane w niskiej, rozproszonej zabudowie (22; 11\%), 3 - zbiorniki w parkach miejskich $(6$; $3 \%$ ), 4 - zbiorniki w lasach podmiejskich ( 10 zbiorników; $5 \%$ ), 5 - zbiorniki w terenie otwartym, ruderalnym z elementami działalności przemysłowej $(26 ; 13 \%), 6$ - zbiorniki w terenie otwartym, ruderalnym, minimalnie przeksztalconym przez czlowieka oraz wśród pól $(114 ; 57 \%), 7$ - zbiorniki w ogrodach dzialkowych $(7 ; 3,5 \%), 8$ - zbiorniki polożone w ekotonie terenów otwartych i leśnych $(10 ; 5 \%)$. Liczebność gatunków określano metodą taksacji brzegowej, wspartą oceną liczebności na podstawie wydawanych glosów godowych. Wykonano 3-4 kontrole każdego zbiornika wodnego w sezonie. Liczebność szacowano z użyciem skali iloczynowej $2 x$, gdzie 1 - oznaczalo liczebność do 5 osobników, 2 - do 10,3 - do 20,4 - do 40, 5 - do 80,6 - do 160,7 - do 320,8 - do 
640, 9 - do 1280, 10 - powyżej 1280 osobników. Liczebność gatunku określono przyjmując najwyższą odnotowaną w ciagu sezonu liczbę osobników, zaś estymację średniej liczby plazów przebywających w zbiorniku wodnym oparto o środki przedzialów przyjętej skali (żabę jeziorkową Rana lessonae i żabę wodną Rana esculenta potraktowano lącznie jako grupę żab zielonych Rana esculenta complex).

Obecność plazów stwierdzono w 167 zbiornikach $(83,5 \%)$, wśród zbiorników zasiedlonych przez plazy $73(43,7 \%)$ to zbiorniki okresowe, zaś $94(56,3 \%)$ zbiorniki trwale. Stwierdzono 11 gatunków plazów: traszkę zwyczajną Triturus vulgaris, traszkę grzebieniastą Triturus cristatus, ropuchę szarą Bufo bufo, ropuchę zieloną Bufo viridis, grzebiuszkę ziemna Pelobates fuscus, kumaka nizinnego Bombina bombina, rzekotkę drzewną Hyla arborea, żabę trawna Rana temporaria, żabę moczarową Rana arvalis, żabę wodną Rana esculenta i żabę jeziorkową Rana lessonae. Spośród gatunków stwierdzanych na Pojezierzu Olsztyńskim, w Olsztynie nie odnotowano ropuchy paskówki Bufo calamita i żaby śmieszki Rana ridibunda. Najbardziej rozpowszechnionym taksonem byly żaby zielone ( $71,9 \%$ zbiorników zajętych przez plazy; $60,0 \%$ wszystkich zbiorników) i żaba trawna $(64,1 \% ; 53,5 \%)$, najniższą frekwencję mialy: rzekotka drzewna $(6,0 \% ; 5,0 \%)$, ropucha zielona $(5,4 \% ; 4,5 \%)$ i traszka grzebieniasta $(3,6 \%$; $3,0 \%$ ). Najczęściej zbiorniki byly zasiedlane przez 1-3 gatunki (ponad 50\% wszystkich zbiorników z plazami). Zróżnicowanie liczby gatunków i składu gatunkowego zależalo od typu otoczenia zbiornika wodnego. Sklad gatunkowy plazów Olsztyna byl zbliżony do zespolów notowanych w innych dużych miastach Polski, a różnice między miastami byly efektem geograficznego występowania populacji oraz zanikiem stanowisk trzech najbardziej wrażliwych na urbanizację gatunków: ropuchy paskówki, rzekotki drzewnej i kumaka nizinnego. W strukturze ilościowej zespolu plazów Olsztyna wyraźnie dominowały żaby zielone, zasiedlając zarówno strefę peryferyjna, jak i centrum miasta. Zespól płazów Olsztyna w porównaniu do innych miast charakteryzowal się wielokrotnie wyższą ogólną liczebnością. W pracy przeprowadzono szeroką dyskusję uwarunkowań struktury gatunkowej i liczebności zespołów płazów w miastach.

Accepted: 20 January 2011 